\title{
THE EFFECT OF REYNOUTRIA $\times$ BOHEMICA ON THE CONDITION OF CAPREOLUS CAPREOLUS AND CERVUS ELAPHUS
}

\author{
MARTIN ERNST $^{1 *}$, PETR MADĚRA ${ }^{2}$, TOMÁŠ FRANTÍK $^{2}$, JAN NOVÁK $^{3}$, \\ ŠTĚPÁN VENCL ${ }^{4}$
}

\author{
${ }^{1}$ Department of Forest Protection and Wildlife Management, Faculty of Forestry and Wood \\ Technology, Mendel University in Brno, Zemédělská 3, Brno, 613 00, Czech Republic \\ ${ }^{2}$ Department of Forest Botany, Dendrology and Geobiocoenology, Faculty of Forestry and \\ Wood Technology, Mendel University in Brno, Zemědělská 3, Brno, 613 00, Czech \\ Republic \\ ${ }^{3}$ Dibaq, a.s., Helvikovice 90, Žamberk, 564 01, Czech Republic \\ ${ }^{4}$ Veterinary office, Jirchářská 217, Kostelec nad Orlicí, 517 41, Czech Republic \\ *Corresponding author: ernst@email.cz.
}

Received: $16^{\text {th }}$ April 2021, Accepted: $20^{\text {th }}$ April 2021

\begin{abstract}
The objective of the work is to evaluate the effects of a granulated feeding mixture enriched with knotweed (Reynoutria $\times$ bohemica) on roe deer (Capreolus capreolus) bred at a closed farm and red deer (Cervus elaphus) bred at a farm. Based on both biochemical and haematological blood analysis, the knotweed is expected to have an influence on the microbiome in the digestive system as well as allowing better utilisation of fodder and lower manifestation of pathogenic organisms. The results are of practical use mainly on farms and in hobby breeding but also in deer parks. Furthermore, the results may be used for feeding deer in open hunting grounds.
\end{abstract}

Keywords: roe deer; red deer; granulated feeding mixture; Bohemian knotweed; biochemical analysis of the blood; haematological analysis of the blood

\section{INTRODUCTION}

The nutrition of animals represents an overall complex of animal care that summarises expertise about animals' biology, their physiological needs and the proper administration of fodder according to time and the animals' requirements. Proper nutrition is an inseparable part of animal care and one of the key factors for achieving good condition and constitution as well as increasing the breeding quality of animals in both closed farms and the wild.

Scherer et al. (2019) state that the basis of the understanding of deer is the fact that they are ruminants: herbivores with foreguts and specialised stomachs. All ruminants need stress-free conditions for proper food intake because stress disturbs rumination, which, in a nutshell, represents a complex biochemical process of digestion and using biologically useful substances to meet the ruminant's needs. Last but not least, it is necessary to realise that any sudden change in a ruminant's diet may have fatal consequences due to acidosis. Therefore, proper nutrition is an inseparable part of animal care and one of the key factors for achieving 
a good condition and constitution as well as increasing the breeding and trophy quality of deer. Much has been written about nutrition in books and professional magazines, many scientific works have been devoted to it and it is still discussed as one of the key topics in hunting practice. Despite all these facts, there are often mistakes in the field of nutrition and many hunters, due to their ignorance, hurt animals rather than helping them. To understand all aspects related to the nutrition and feeding of deer, it is necessary to know that these animals do not live directly on what they consume but on what microorganisms living in their digestive system create from said food. The products of their metabolism are carbon dioxide, methane and volatile fatty acids. The gases are secreted, and the acids are usually absorbed through the rumen wall and further metabolised in the organism. Microbial biomass is also used as a source of energy, proteins and other nutrients. Fully $70 \%$ of a needed dose of energy is usually ensured by volatile fatty acids of bacterial origin, and a ruminant gains $20 \%$ of its energy from microbial mass created in the rumen. Thus, a ruminant depends on microorganisms for $90 \%$ of its energy, and the remaining $10 \%$ of comes from nutrients that have avoided fermentation. If proper conditions for these microorganisms are not ensured, a ruminant can have the best quality food available in unlimited quantities and still be starving.

To understand all the contexts related to nutrition and animal feeding, it is necessary to state that our landscape and environment have changed significantly during evolution. Natural biotopes are giving way to agriculture and forest management, which forces animals to assimilate to constantly changing conditions. The situation is improving in forest ecosystems where mixed or deciduous stands are preferred and where more natural management with sustainable development is increasingly used. However, in our cultural landscape, animals are also dependent on human help.

For Bohemian knotweed (Reynoutria $\times$ bohemica), it is possible to assume positive effects similar to those described by several authors for Japanese knotweed (Polygonum japonicum, syn. Reynoutria japonica), which is also ranked among dangerous invasive plants in the Czech Republic (Mandák et al., 2004) and in entire temperate zone of the Northern Hemisphere (Claude, 2017; Shaw et al., 2009; Luque et al., 2014).

For resveratrol and piceid contained in the knotweed, antioxidation properties have been proven, and piceid seems to be more effective than resveratrol (Jacob et al., 2014). Resveratrol has shown a strong potential to reduce the stress of weaned piglets: it has influenced growth, immunity, the usability of nutrients from fodder and the microbial composition of excrement. It acts as an alternative to antibiotics (Ahmed et al., 2013). Holešovská et al. (2009) found that resveratrol reduced the value of leucocytes in pigs, which also shows its anti-inflammatory effects. That is why similar effects are also expected in hoofed deer.

Cui et al. (2018) studied the influence of resveratrol, administrated to piglets for three weeks together with a basic fodder, on diarrhoea after infection induced by RV rotaviruses. They observed diarrhoea reduction, lower creation of TNF- $\alpha$ and increase in IFN- $\gamma$ values. These results show that resveratrol may be used for the control of infections caused by rotaviruses. Maděra et al. (2021) found positive effects of Bohemian knotweed in pig diet, especially on lipid metabolism of gilts.

Kohnen et al. (2007) and Zambito (2011) described imbibitional effects of resveratrol on neutrophil myeloperoxidase. Lawless (2010) found that the application of one gram of resveratrol per day for four weeks reduced the inflammatory formation of cytokinin in twenty-year-old horses, using both in vitro and in vivo experiments; therefore, it has significant therapeutical potential to treat acute and chronical inflammatory diseases in horses. Horse trainers and horse owners has observed better health, calmness and 
Ernst M., Maděra P., Frantík T., Novák J., Vencl Š.: The Effect of Reynoutria $\times$ bohemica on the Condition of Capreolus capreolus and Cervus elaphus

performance in horses given resveratrol. Handler (2011) and Rowen (2013) state that resveratrol reduces the genetic expression of inflammatory mediators and allows horses to move freely during aging, training and competitions. Lawless (2010) states that daily administration of resveratrol improves energetic metabolism in horses by acting on mitochondria, which serve as a 'power station' of the body.

In vitro tests on laboratory animals and clinical studies in human medicine show antibacterial effects (Chan, 2002; Docherty et al., 2001), antifungal effects (Adrian et al., 1997; Bavaresco et al., 2001, 2003; Filip et al., 2003; Jung et al., 2005; Schulze et al., 2005), antiparasitic effects (Anantaphruti et al., 1982), anti-cancer effects (Ferry-Dumazet et al., 2002; Roman et al., 2002; Ulrich et al., 2005; Wolter et al., 2004; El-Mowafy et Alkhalaf, 2003; Lu et al., 2008; Muto et al., 2007; Fu et al., 2007; Pecere et al., 2000; Jeong et al., 2010; Pezzuto, 2008), effects against vascular diseases and other diseases of the developed world, even those related to obesity and diabetes (Kerem et al., 2006; Dal-Pan et al., 2010; Brasnyo et al., 2011).

The objective of the work is to evaluate the effects of a granulated feeding mixture enriched with knotweed (Reynoutria $\times$ bohemica) on roe deer (Capreolus capreolus) bred at a closed farm and red deer (Cervus elaphus) bred at a farm.

\section{MATERIAL AND METHODS}

Based on the above stated results of research works, knotweed was chosen for testing in roe deer and red deer. For two years, we tested a group of seven roe deer and 22 red deer, to which a granulated feeding mixture with an addition of knotweed was administered, as well as a control group of six roe deer and 18 red deer to which a feeding mixture without knotweed was administered. For the roe deer, a veterinarian took blood samples from a vein on a front limb, after the males had shed their antlers, while every individual was immobilised by an anaesthetic shot. For the red deer, the blood sample was taken from a neck vein or from a vein at a tail root in a fixation device (so-called crash) in the first two months of the year following the experiment. Subsequently, the blood samples were biochemically analysed at Medila by an MV specialising in haematology, Dr. Štěpán Vencl. Values of ALT, AST, ALP, GMT, urea, creatinine, total protein, albumin, A/G ratio, globulins, glucoses, triglycerides, cholesterol, $\mathrm{CK}$, bilirubin $\mathrm{T}$ and bilirubin $\mathrm{P}$ were biochemically specified; values of leukocytes, erythrocytes, haemoglobin, haematocrit, $\mathrm{MCV}, \mathrm{MCH}, \mathrm{MCHC}$, neutrophiles, eosinophiles, basophiles, lymphocytes and monocytes were specified haematologically. The group fed with the addition of knotweed and the group fed without the addition were evaluated separately using statistical methods.

\section{RESULTS AND DISCUSSION}

\section{Roe deer (Capreolus capreolus)}

Significantly different results between the group of deer fed a mixture with the addition of knotweed and the group fed on a mixture without knotweed were found in the content of urea, bilirubin $\mathrm{T}$ and lymphocytes. No statistically significant results were found in other monitored biochemical and haematological parameters, so they are not described in detail here. For an overview, however, we present the range of measured values from biochemical and haematological analysis of blood from the entire period of the experiment in the following tables. 
Table 1: The range of biochemical values measured within the monitored groups of roe deer.

\begin{tabular}{|c|c|c|c|c|c|}
\hline \multirow[t]{2}{*}{ Biochemical value } & \multirow[t]{2}{*}{ Unit } & \multicolumn{2}{|c|}{ The group with knotweed } & \multicolumn{2}{|c|}{$\begin{array}{c}\text { The group without } \\
\text { knotweed }\end{array}$} \\
\hline & & $\min$. & $\max$. & $\min$. & $\max$. \\
\hline ALT & $\mu \mathrm{kat} / 1$ & 0.44 & 1.79 & 0.42 & 0.88 \\
\hline AST & $\mu \mathrm{kat} / 1$ & 0.95 & 2.04 & 0.99 & 1.94 \\
\hline ALP & $\mu \mathrm{kat} / 1$ & 0.36 & 1.90 & 0.39 & 1.45 \\
\hline GMT & $\mu \mathrm{kat} / 1$ & 1.29 & 2.39 & 1.26 & 2.12 \\
\hline Urea & $\mathrm{mmol} / \mathrm{l}$ & 6.90 & 11.00 & 7.40 & 24.50 \\
\hline Creatinine & $\mu \mathrm{mol} / 1$ & 27.00 & 121.00 & 78.00 & 212.00 \\
\hline Total protein & $\mathrm{g} / \mathrm{l}$ & 59.00 & 86.80 & 61.20 & 88.70 \\
\hline Albumin & $\mathrm{g} / \mathrm{l}$ & 29.60 & 76.00 & 29.30 & 41.30 \\
\hline Globulins & $\mathrm{g} / \mathrm{l}$ & 23.70 & 53.40 & 30.50 & 56.10 \\
\hline $\mathrm{A} / \mathrm{G}$ ratio & & 0.55 & 1.56 & 0.58 & 1.16 \\
\hline Glucose & $\mathrm{mmol} / \mathrm{l}$ & 5.90 & 21.51 & 8.81 & 30.29 \\
\hline Triglycerides & $\mathrm{mmol} / \mathrm{l}$ & 0.08 & 0.70 & 0.13 & 1.06 \\
\hline Cholesterol & $\mathrm{mmol} / \mathrm{l}$ & 0.90 & 5.82 & 0.81 & 2.03 \\
\hline CK & $\mu \mathrm{kat} / 1$ & 2.82 & 22.77 & 1.72 & 28.15 \\
\hline Bilirubin $\mathrm{T}$ & $\mu \mathrm{mol} / 1$ & 2.10 & 5.40 & 2.40 & 7.20 \\
\hline Bilirubin P & $\mu \mathrm{mol} / 1$ & 1.70 & 2.80 & 1.70 & 4.10 \\
\hline
\end{tabular}


Ernst M., Maděra P., Frantík T., Novák J., Vencl Š.: The Effect of Reynoutria $\times$ bohemica on the Condition of Capreolus capreolus and Cervus elaphus

Table 2: The range of haematological values measured within the monitored groups of roe deer.

\begin{tabular}{|c|c|c|c|c|c|}
\hline \multirow[t]{2}{*}{ Haematological value } & \multirow[t]{2}{*}{ Unit } & \multicolumn{2}{|c|}{ The group with knotweed } & \multicolumn{2}{|c|}{$\begin{array}{c}\text { The group without } \\
\text { knotweed }\end{array}$} \\
\hline & & $\min$. & $\max$. & $\min$. & $\max$. \\
\hline Leucocytes & $\times 10^{9} / 1$ & 1.80 & 5.90 & 1.20 & 6.40 \\
\hline Erythrocytes & $\times 10^{12} / 1$ & 8.89 & 13.88 & 8.57 & 13.80 \\
\hline Haemoglobin & $\mathrm{g} / \mathrm{l}$ & 128.00 & 198.00 & 128.00 & 196.00 \\
\hline Haematocrit & $1 / 1$ & 0.430 & 0.750 & 0.420 & 0.740 \\
\hline $\mathrm{MCV}$ & $\mathrm{fl}$ & 42.51 & 82.06 & 34.13 & 55.31 \\
\hline $\mathrm{MCH}$ & pg & 12.39 & 20.13 & 10.24 & 14.94 \\
\hline $\mathrm{MCHC}$ & $\mathrm{g} / \mathrm{l}$ & 243.55 & 336.36 & 255.41 & 315.52 \\
\hline Neutrophils seg. & $\times 10^{9} / 1$ & 0.380 & 3.300 & 0.429 & 4.190 \\
\hline Neutrophils seg. & $\%$ & 14.00 & 55.00 & 28.00 & 71.00 \\
\hline Eosinophiles & $\times 10^{9} / 1$ & 0.000 & 0.720 & 0.000 & 0.512 \\
\hline Eosinophiles & $\%$ & 0.00 & 12.00 & 0.00 & 13.00 \\
\hline Basophiles & $\times 10^{9} / 1$ & 0.000 & 0.068 & 0.000 & 0.064 \\
\hline Basophiles & $\%$ & 0.00 & 2.00 & 0.00 & 2.00 \\
\hline Monocytes & $\times 10^{9} / 1$ & 0.000 & 0.189 & 0.000 & 1.690 \\
\hline Monocytes & $\%$ & 0.00 & 4.00 & 0.00 & 65.00 \\
\hline Lymphocytes & $\times 10^{9} / 1$ & 1.026 & 3.364 & 0.052 & 3.438 \\
\hline Lymphocytes & $\%$ & 30.00 & 83.00 & 2.00 & 63.00 \\
\hline
\end{tabular}

A statistically significant result was observed in urea concentration, where the values found in the blood of roe deer fed a mixture with the addition of knotweed were lower than in roe deer fed normally (see Fig. 1). It was similar in year 2018, but the results were not statistically significant. Given the fact that, in mammals, urea is created as a metabiological product during the degradation of amino acids (where the created ammonia is bound and excreted in the form of urea), the results show that there is enough protein in the fodder. It is also possible to assume the positive influence of knotweed on the microbiome in the GIT. Suppression of potentially pathogenic organisms may occur, as may the support of beneficial 
bacteria, particularly the ones that play an important role in the metabolism of nitrogenous substances using ammonia for synthesis of their own proteins (less ammonia is then absorbed into the blood, resulting in less urea as a detoxication product). Again, that would be in accordance with works that claim that resveratrol has a positive influence on dysbiosis in the GIT and returns everything back to normal. Küker et al. (2015) found average values in deer to be $6.24 \pm 0.37 \mathrm{mmol} / 1$, and Žele \& Vengušt (2012) found $6.3 \pm 2.7 \mathrm{mmol} / \mathrm{l}$. The results found in individuals fed a feed mixture with the knotweed addition are closest to these values.

Fig. 1: The urea content for roe deer fed on the feeding mixture with the knotweed addition and without the knotweed addition in the year 2019. Mean \pm S.D. Asterisk indicates difference between treatments significant at $\mathbf{P}=0.05$.

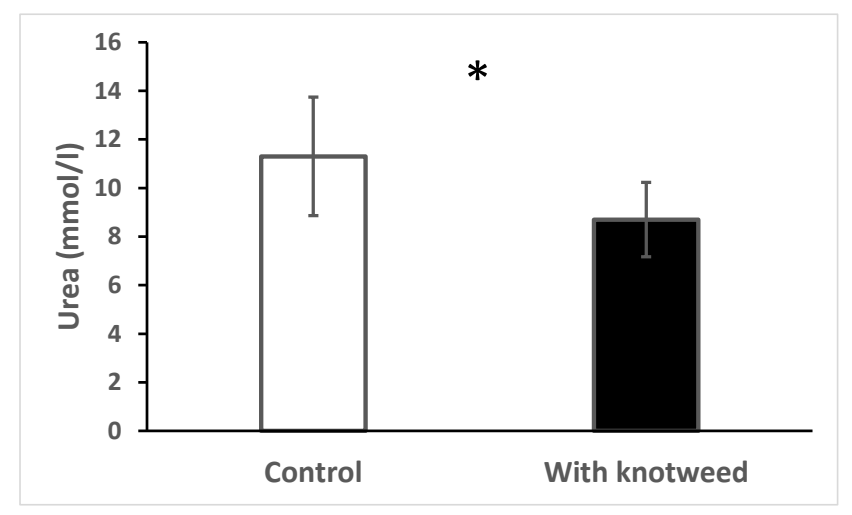

Also statistically significant were the values of bilirubin $\mathrm{T}$, which were lower in the blood of roe deer fed on the mixture with the knotweed addition than in the blood of roe deer fed normally (see Fig. 2). It was similar in year 2018, but the results were not statistically significant. Reduction in bilirubin levels occurs during excessive energy intake and after enzymatic inductors.

Fig. 2: Bilirubin $T$ values in roe deer fed on a feeding mixture with the knotweed addition and without the knotweed addition in the year 2019. Mean \pm S.D. Asterisk indicates difference between treatments significant at $\mathbf{P}=0.05$.

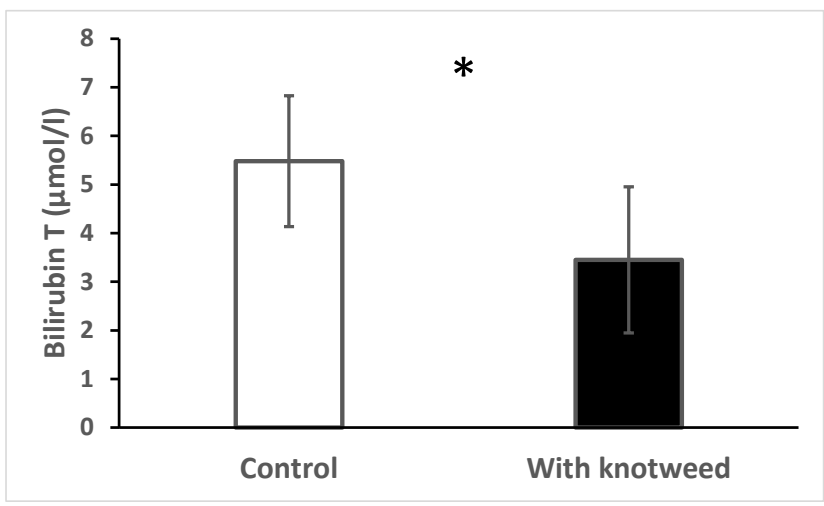


The value of total bilirubin reflects the balance between haem release and uptake, storage, conjugation and excretion of bilirubin alone, so there is a whole range of causes (prehepatic, hepatic and post-hepatic). In most cases, however, it is an indicator of cholestasis, but here we see low values - most likely a physiological range again, but its slight increase may be result of anorexia, starvation, GIT disease, infection, ketosis or physical exertion. When comparing average values with the work of Küker et al. (2015), who give figures of $5.5 \pm 0.3$ $\mu \mathrm{mol} / \mathrm{l}$, the individuals fed without knotweed are closest to their results, and the individuals fed with the knotweed addition show lower values.

The last statistically significant result in roe deer is the proven lower content of lymphocytes in the blood of roe deer males fed on a feeding mixture without the knotweed addition compared with the males fed on a feeding mixture with the knotweed addition. In females, the values are almost identical, but there are insignificant results (see Fig. 3). The reduction in the lymphocyte value may be caused by stress during the blood sampling together with the increased value of neutrophiles. It cannot be assumed that the feeding mixture with or without knotweed has had an influence on these values. The increased value of lymphocytes may also occur due to an allergic reaction. Küker et al. (2015) found values of $2.40 \pm 0.12 \times 109 / 1 \mathrm{in}$ roe deer, which is comparable to the values in both groups, while the group fed on a mixture with the knotweed addition is closest to them.

Fig. 3: The content of lymphocytes in roe deer fed on the feeding mixture with the knotweed addition and without the knotweed addition after experiment in the year 2019 according to sex. Mean \pm S.D. Asterisk indicates difference between treatments significant at $\mathbf{P}=\mathbf{0 . 0 5}$.

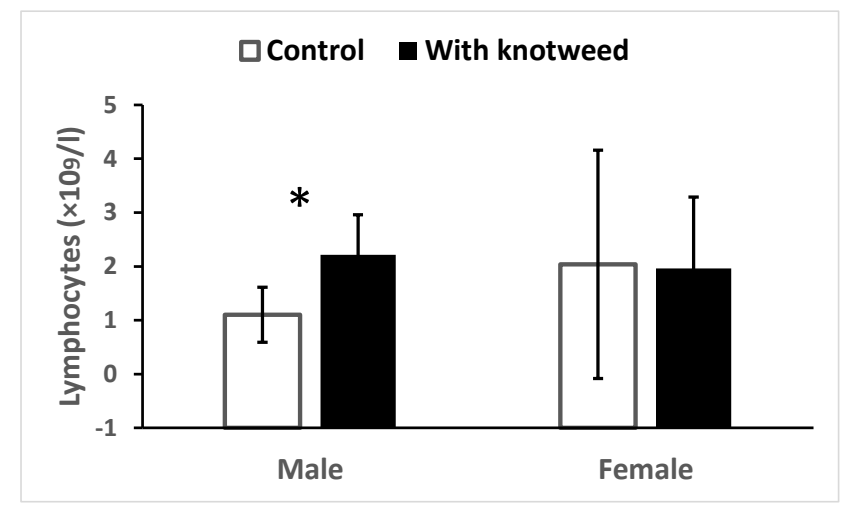

\section{Red deer (Cervus elaphus)}

Significantly different results were observed between red deer fed with the knotweed addition (males) and the group fed without the knotweed (females) in terms of the content of urea, creatinine, total protein, globulin, A/G ratio, triglycerides, cholesterol, bilirubin $\mathrm{T}$, bilirubin P, leukocytes, neutrophiles, eosinophiles, basophiles and lymphocytes. No statistically significant results were found in other monitored biochemical and haematological parameters, so they are not described in detail here. For an overview, however, we present the range of measured values from biochemical and haematological analysis of blood from the entire period of the experiment in the following tables. 
Table 3: The range of biochemical values measured within monitored groups of red deer.

\begin{tabular}{|c|c|c|c|c|c|}
\hline \multirow[t]{2}{*}{ Biochemical value } & \multirow[t]{2}{*}{ Unit } & \multicolumn{2}{|c|}{ The group with knotweed } & \multicolumn{2}{|c|}{$\begin{array}{l}\text { The group without } \\
\text { knotweed }\end{array}$} \\
\hline & & $\min$. & $\max$. & $\min$. & $\max$. \\
\hline ALT & $\mu \mathrm{kat} / \mathrm{l}$ & 0.53 & 2.05 & 1.09 & 2.18 \\
\hline AST & $\mu \mathrm{kat} / \mathrm{l}$ & 0.72 & 2.31 & 1.06 & 2.65 \\
\hline ALP & $\mu \mathrm{kat} / \mathrm{l}$ & 0.58 & 3.77 & 0.45 & 20.00 \\
\hline GMT & $\mu \mathrm{kat} / \mathrm{l}$ & 0.33 & 0.73 & 0.39 & 1.40 \\
\hline Urea & $\mathrm{mmol} / \mathrm{l}$ & 2.80 & 12.00 & 5.10 & 17.80 \\
\hline Creatinine & $\mu \mathrm{mol} / 1$ & 81.00 & 185.00 & 94.00 & 211.00 \\
\hline Total protein & $\mathrm{g} / \mathrm{l}$ & 52.60 & 86.40 & 64.40 & 80.80 \\
\hline Albumin & $\mathrm{g} / \mathrm{l}$ & 23.40 & 33.70 & 26.10 & 34.80 \\
\hline Globulins & $\mathrm{g} / \mathrm{l}$ & 28.10 & 52.70 & 34.60 & 50.10 \\
\hline $\mathrm{A} / \mathrm{G}$ ratio & & 0.57 & 1.00 & 0.59 & 0.91 \\
\hline Glucose & $\mathrm{mmol} / \mathrm{l}$ & 3.19 & 7.52 & 4.17 & 9.01 \\
\hline Triglycerides & $\mathrm{mmol} / \mathrm{l}$ & 0.11 & 0.33 & 0.10 & 0.29 \\
\hline Cholesterol & $\mathrm{mmol} / \mathrm{l}$ & 0.77 & 2.17 & 1.02 & 2.22 \\
\hline $\mathrm{CK}$ & $\mu \mathrm{kat} / 1$ & 1.50 & 51.49 & 1.52 & 14.79 \\
\hline Bilirubin $\mathrm{T}$ & $\mu \mathrm{mol} / 1$ & 2.10 & 23.60 & 2.00 & 12.90 \\
\hline Bilirubin P & $\mu \mathrm{mol} / 1$ & 1.80 & 7.30 & 1.80 & 7.20 \\
\hline
\end{tabular}


Ernst M., Maděra P., Frantík T., Novák J., Vencl Š.: The Effect of Reynoutria $\times$ bohemica on the Condition of Capreolus capreolus and Cervus elaphus

Table 4: The range of haematological values measured within monitored groups of red deer.

\begin{tabular}{|c|c|c|c|c|c|}
\hline \multirow[t]{2}{*}{ Haematological value } & \multirow[t]{2}{*}{ Unit } & \multicolumn{2}{|c|}{ The group with knotweed } & \multicolumn{2}{|c|}{$\begin{array}{c}\text { The group without } \\
\text { knotweed }\end{array}$} \\
\hline & & $\min$. & $\max$. & $\min$. & $\max$. \\
\hline Leucocytes & $\times 10^{9} / 1$ & 2.40 & 12.80 & 2.70 & 8.00 \\
\hline Erythrocytes & $\times 10^{12} / 1$ & 6.94 & 15.01 & 8.99 & 15.15 \\
\hline Haemoglobin & $\mathrm{g} / \mathrm{l}$ & 116.00 & 207.00 & 145.00 & 204.00 \\
\hline Haematocrit & $1 / 1$ & 0.320 & 0.660 & 0.420 & 0.640 \\
\hline $\mathrm{MCV}$ & $\mathrm{fl}$ & 32.26 & 59.34 & 34.41 & 59.32 \\
\hline $\mathrm{MCH}$ & pg & 12.37 & 21.05 & 11.83 & 17.24 \\
\hline $\mathrm{MCHC}$ & $\mathrm{g} / \mathrm{l}$ & 261.67 & 470.45 & 252.46 & 372.92 \\
\hline Neutrophils seg. & $\times 10^{9} / 1$ & 0.480 & 11.140 & 0.990 & 5.920 \\
\hline Neutrophils seg. & $\%$ & 17.00 & 94.50 & 28.00 & 76.00 \\
\hline Eosinophiles & $\times 10^{9} / 1$ & 0.000 & 0.760 & 0.000 & 0.640 \\
\hline Eosinophiles & $\%$ & 0.00 & 10.00 & 0.00 & 12.00 \\
\hline Basophiles & $\times 10^{9} / 1$ & 0.000 & 0.320 & 0.000 & 0.110 \\
\hline Basophiles & $\%$ & 0.00 & 5.00 & 0.00 & 2.00 \\
\hline Monocytes & $\times 10^{9} / 1$ & 0.000 & 0.390 & 0.000 & 0.300 \\
\hline Monocytes & $\%$ & 0.00 & 9.00 & 0.00 & 6.00 \\
\hline Lymphocytes & $\times 10^{9} / 1$ & 0.460 & 5.330 & 0.860 & 3.530 \\
\hline Lymphocytes & $\%$ & 4.50 & 78.00 & 21.00 & 65.50 \\
\hline
\end{tabular}

The change of urea content in the blood of red deer fed on a mixture with the knotweed addition was lower than in the group of red deer fed normally, and the results are statistically significant (see Fig. 4). From the differences between the tested groups, it is possible to assume a positive influence on the microbiome in the GIT. A suppression of potentially pathogenic organisms may occur, as may the support of beneficial bacteria, particularly the ones that play an important role in the metabolism of nitrogenous substances using ammonia for synthesis of their own proteins. Again, this would be in accordance with works that claim that resveratrol has a positive influence on dysbiosis in GIT and returns everything back to 
normal. Marco \& Lavín (1999) found the average value to be $8.09 \pm 2.72 \mathrm{mmol} / \mathrm{l}$ for red deer, and the values measured in the group with the knotweed addition are closest to their results. On the contrary, values measured in the group fed the mixture without the knotweed addition are closest to the results found by Barić Rafaj et al. (2011) $(11.1 \pm 3.18 \mathrm{mmol} / \mathrm{l})$.

Fig. 4: The change of urea content during experiment in red deer fed on the feeding mixture with the knotweed addition and without the knotweed addition. Mean \pm S.D. Asterisk indicates difference between treatments significant at $\mathbf{P}=\mathbf{0 . 0 5}$.

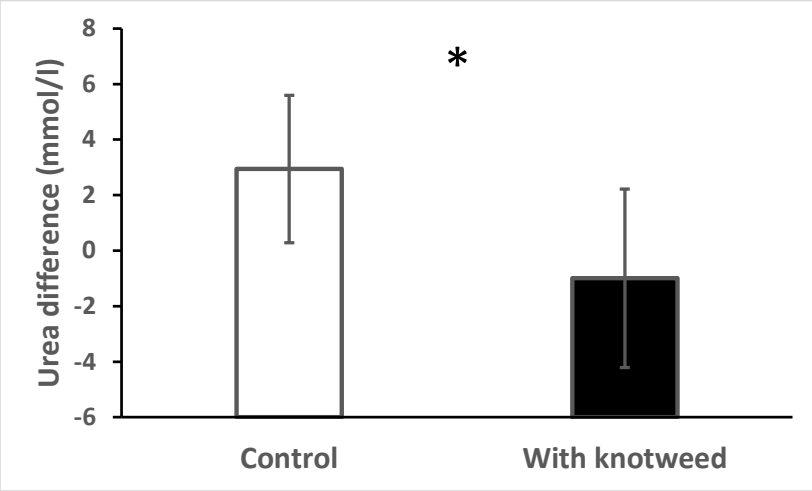

A statistically significant result was observed in the change of creatinine content in the blood of red deer fed on the feeding mixture without the addition of knotweed compared to the blood of red deer fed on the feeding mixture with the knotweed addition (see Fig. 5). The creatinine concentration in a serum is directly proportional to the muscle mass of the organism; for this reason, it is slightly higher in male deer and lower in fawns and those with a lower volume of muscle mass. Higher values may be not only in the kidneys but also, for example, in the case of dehydration (however, other indicators would, in this case, also be higher).

Fig. 5: The change of creatinine content during experiment in red deer fed on the feeding mixture with the knotweed addition and without the knotweed addition. Mean \pm S.D. Asterisk indicates difference between treatments significant at $P=0.05$.

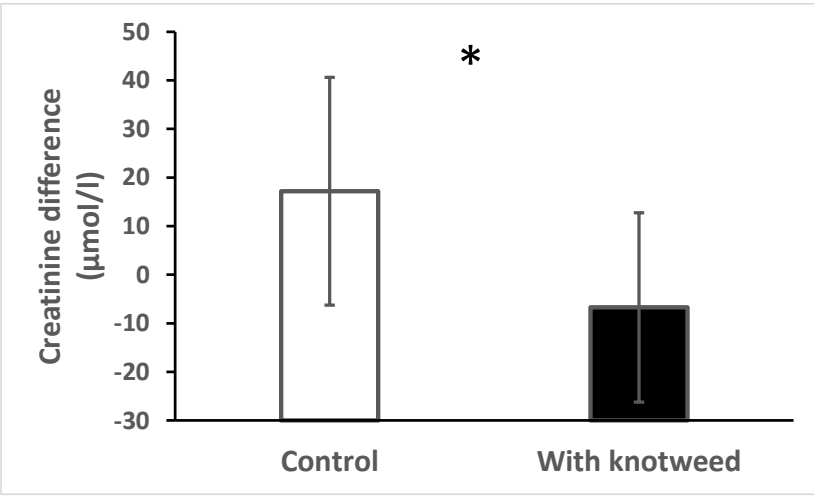

The resulting values are relatively low and, therefore, physiological; the different ages of animals, the state of their hydration, etc. may also have an impact here. Values observed by 
Ernst M., Maděra P., Frantík T., Novák J., Vencl Š.: The Effect of Reynoutria $\times$ bohemica on the Condition of Capreolus capreolus and Cervus elaphus

us are, similarly to the urea values, closer to the results of Marco \& Lavín (1999) - 147.6 \pm $29.2 \mu \mathrm{mol} / 1$ in individuals fed on the feeding mixture with the knotweed addition - and in the group fed normally, our results are close to the work of Barić Rafaj et al. (2011): $164 \pm 60.94$ $\mu \mathrm{mol} / \mathrm{l}$.

The total protein content in the blood of red deer was also statistically significant, and lower content was observed in red deer fed on the feeding mixture with the knotweed addition. Total protein consists of a set of several hundred different proteins, which are formed mainly in the liver and thence released into the blood. The reduction of total protein may cause a protein deficit in a diet, malabsorption, hepatic impairment due to decreased proteosynthesis, chronic rumen dysfunction due to reduced microbial protein synthesis, exudative enteropathy due to the intestinal protein loss, nephrotic syndrome due to protein loss by the kidneys, bleeding or septic conditions. A suppression of potentially pathogenic organisms may occur, as may the support of beneficial bacteria, particularly the ones that play an important role in the metabolism of nitrogenous substances using ammonia for synthesis of their own proteins. It was possible to compare our results with the work of Marco \& Lavín (1999), who give the average value of $65 \pm 6 \mathrm{~g} / \mathrm{l}$, which corresponds most to the values in the group fed with the knotweed addition.

Fig. 6: The content of total protein in red deer fed on the feeding mixture with the knotweed addition and without the knotweed addition after experiment in the year 2020. Mean \pm S.D. Asterisk indicates difference between treatments significant at $\mathbf{P}=\mathbf{0 . 0 5}$.

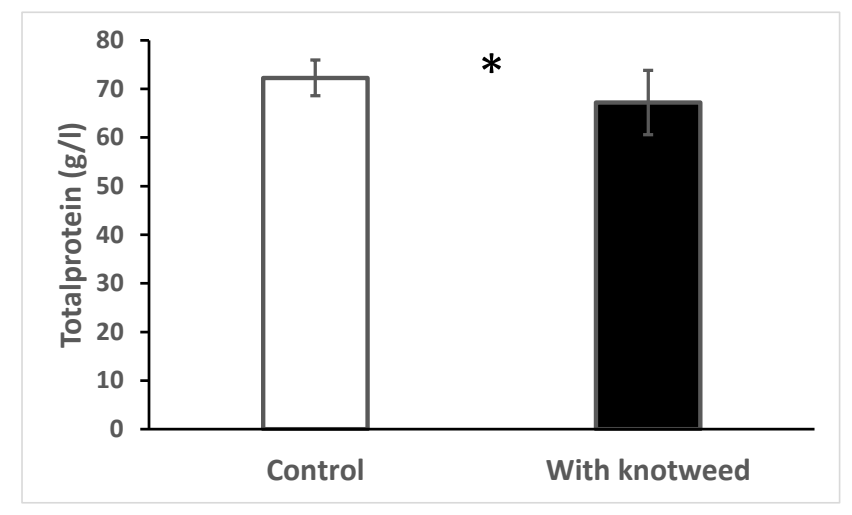

The change of change of globulins content in the blood of red deer fed on the feeding mixture without the knotweed addition compared to red deer fed on the mixture with the knotweed addition, was also significant. Globulins are a group of globular proteins of the blood plasma. The term 'globulin' is quite general and includes a wide range of proteins divided into alpha, beta and gamma groups (immunoglobulins). The most of it is created in livers. Immunoglobulins are a product of lymphatic tissue, specialised cells in an organism's immune system. In terms of immune functions, so-called immunoglobulins are the most significant because they bear antibodies able to eliminate some harmful substances penetrating the body (microorganic particles, foreign cells, poisons, etc.). The value of immunoglobulins is higher during bouts of infectious disease. The reduction of globulin concentration resulting from the experiment may be influenced by reduced liver function or the possibility of the reduced value of immunoglobulins in reaction to a low antigenic load on the organism. It was not possible to compare the results with other authors. 
Fig. 7: The change of change of globulin content during experiment in red deer fed on the feeding mixture with the knotweed addition and without the knotweed addition. Mean \pm S.D. Asterisk indicates difference between treatments significant at $P=0.05$.

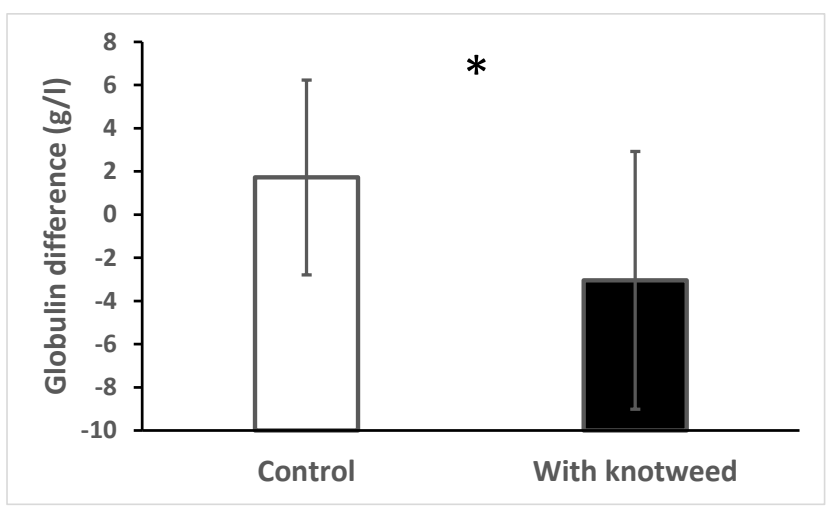

The changes of Albumin/Globulin ratio are lower in red deer fed on the feeding mixture without the knotweed addition compared to the red deer fed on the mixture with the knotweed addition, and the results are statistically significant (see Fig. 8). Albumin is a group of proteins with a low molecular weight; it contributes from $80 \%$ of the maintenance of oncotic pressure and is important for the transport of bilirubin, some fatty acids, calcium, thyroxine and vitamins. In normally fed individuals, an inadequate diet may eventually cause liver insufficiency due to reduced synthesis, exocrine pancreatic insufficiency due to malabsorption, enteropathy due to malabsorption or intestinal loss and nephropathy due to kidney loss or bleeding. Based on the higher $\mathrm{A} / \mathrm{G}$ ratios in red deer fed on the mixture with the knotweed addition, it is possible to assume the sufficient production of albumin together with a lower value of globulins. Again, it was not possible to compare this indicator with other authors.

Fig. 8: The change of Albumin/Globulin ratio during experiment in red deer fed on the feeding mixture with the knotweed addition and without the knotweed addition. Mean \pm S.D. Asterisk indicates difference between treatments significant at $\mathbf{P}=0.05$.

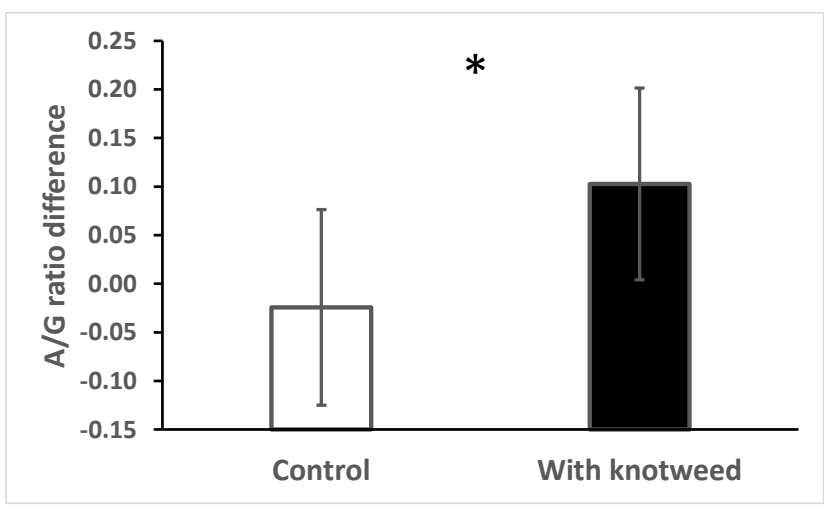

A statistically significant result of the change of triglyceride values in the red deer blood was observed when lower change of values was found in red deer fed on the feeding mixture with the knotweed addition (see Fig. 9). In extreme cases, hypertriacylglycerolemia may be 
caused by a long-term energy deficit in a feed ration (in cattle), liver steatosis, different hepatopathy, a disorder of lipid metabolism or malabsorption. For instance, volatile fatty acids are also a precursor of fat in ruminants, and they are synthesised in the intestines by chosen microorganisms. Again, we can assume a positive influence on the GIT microbiome and better utilisation of nutrients, resulting in, for example, a better fatness of milk. Our value range for both groups corresponds with the average values stated by Barić Rafaj et al. (2011): $0.18 \pm 0.07$ for fawns $\mathrm{mmol} / \mathrm{l}$ a and $0.22 \pm 0.11 \mathrm{mmol} / \mathrm{l}$ for adult individuals. However, the adults tested by us that were fed on the feeding mixture with the knotweed additive are the closest to their average values for an adult individual.

Fig. 9: The change of triglyceride values during experiment in red deer fed on the feeding mixture with the knotweed addition and without the knotweed addition. Mean \pm S.D. Asterisk indicates difference between treatments significant at $\mathbf{P}=0.05$.

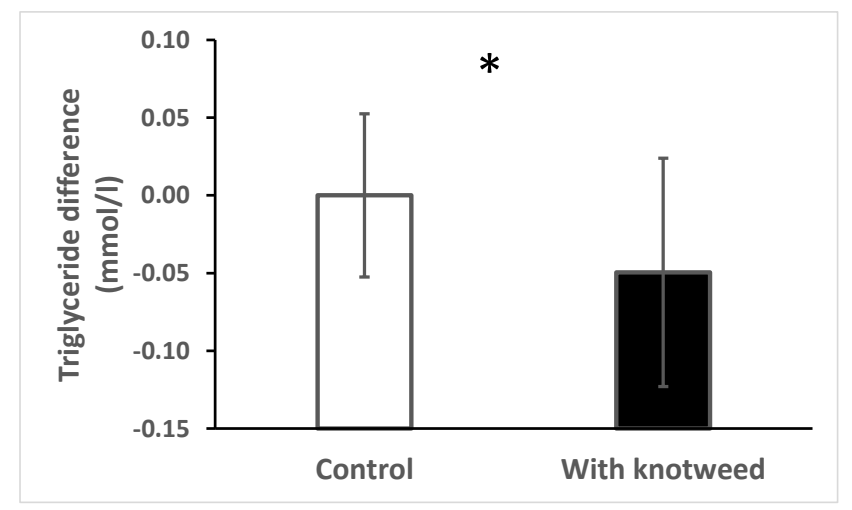

Another statistically significant difference was proven in the change of cholesterol values in the blood of red deer when its values in the red deer fed on the feeding mixture with the knotweed addition was higher. The cholesterol value shows the ability of the liver to excrete fat through protein with low molecule weight. In a diet with high energy and low protein, we can find the lowest cholesterol in blood and the highest liver fattening value due to the inability to remove fat from the liver. Hypercholesterolemia (an increase in concentration above the upper limit of the reference range) can cause diabetes mellitus, hypothyroidism, hyperadrenocorticism (hypertriacylglycerolemia), acute pancreatitis (due to the malabsorption), cholestasis, severe trauma or nephrotic syndrome due to a disorder of lipid metabolism postprandially (higher intake of fat and acetates in ruminants). Marco \& Lavín (1999) found the average value to be $1.29 \pm 0.29 \mathrm{mmol} / \mathrm{l}$ for red deer and Barić Rafaj et al., (2011) found it to be $1.83 \pm 0.91 \mathrm{mmol} / \mathrm{l}$. Our value range for both groups is comparable with the results of these authors, and it is possible to assume that they are within a physiological range. 
Fig. 10: The change of cholesterol values during experiment in red deer fed on the feeding mixture with the knotweed addition and without the knotweed addition. Mean \pm S.D. Asterisk indicates difference between treatments significant at $P=0.05$.

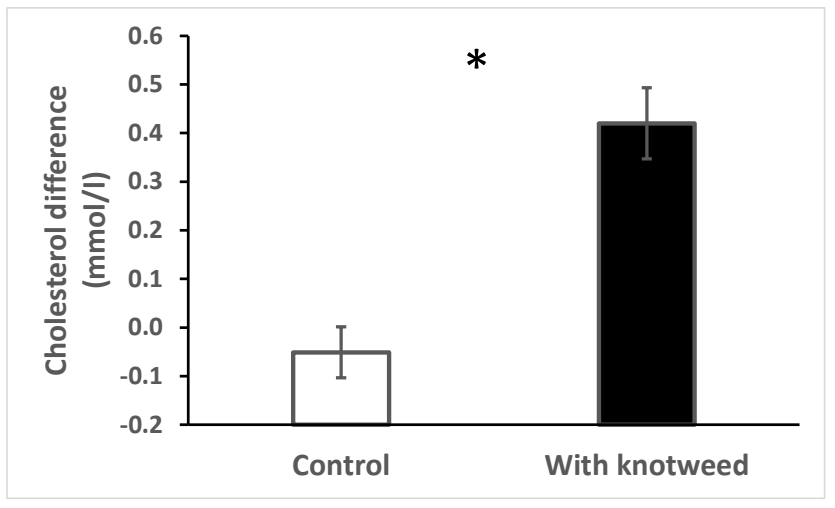

The change of bilirubin $\mathrm{T}$ values are lower in red deer fed on the feeding mixture with the knotweed addition compared to the red deer fed on the mixture without the knotweed addition, and the results are statistically significant (see Fig. 11). The reduction of bilirubin levels occurs with excessive energetic intake and after enzymatic inductors. From the results, it is possible to assume the positive influence of knotweed. Compared to the average value of $15.5 \pm 3.99 \mu \mathrm{mol} / 1$ stated by Barić Rafaj et al., (2011), low values were observed in the vast majority of individuals. The same is true for normally fed individuals.

Fig. 11: Change of bilirubin $T$ values during experiment in red deer fed on the feeding mixture with the knotweed addition and without the knotweed addition. Mean \pm S.D. Asterisk indicates difference between treatments significant at $\mathbf{P}=\mathbf{0 . 0 5}$.

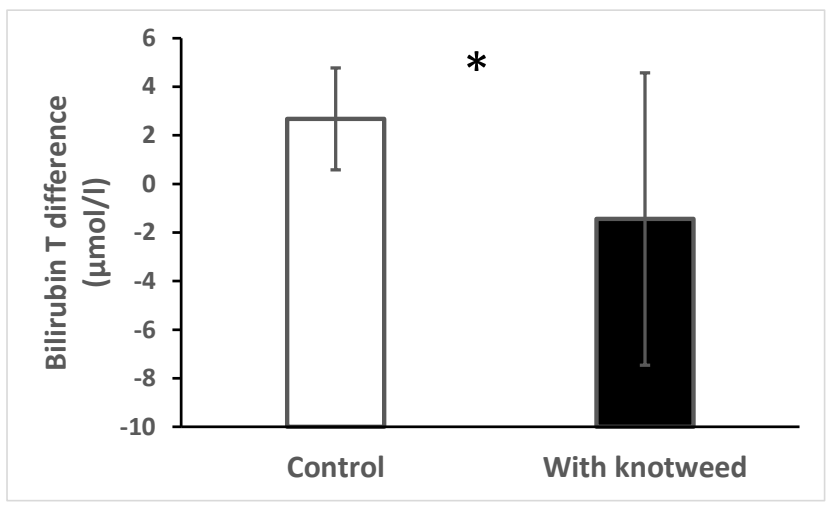

The change of bilirubin $\mathrm{P}$ values are lower in red deer fed on the feeding mixture with the knotweed addition compared to red deer fed on the feeding mixture without the knotweed addition, and the results are statistically significant (see Fig. 12). Bilirubin is created from haem, mainly due to the erythrocytes' breakdown and less due to the breakdown of other haem-containing compounds (myoglobin, cytochromes, catalysis). The created (unconjugated, indirect) bilirubin is transported bind on albumin to the liver, where it is enzymatically conjugated by the UDP enzyme by glucoronyltransferase with glucuronic acid, and conjugated (direct) bilirubin, which is water-soluble, is created. The conjugated 
bilirubin is excreted by bile to the intestines, where the action of bacteria produces other bile pigments. It is possible to assume the positive influence of knotweed from the results. It is not possible to compare the observed value with other authors.

Fig. 12: Change of bilirubin $P$ values during experiment in red deer fed on the feeding mixture with the knotweed addition and without the knotweed addition. Mean \pm S.D. Asterisk indicates difference between treatments significant at $\mathbf{P}=\mathbf{0 . 0 5}$.

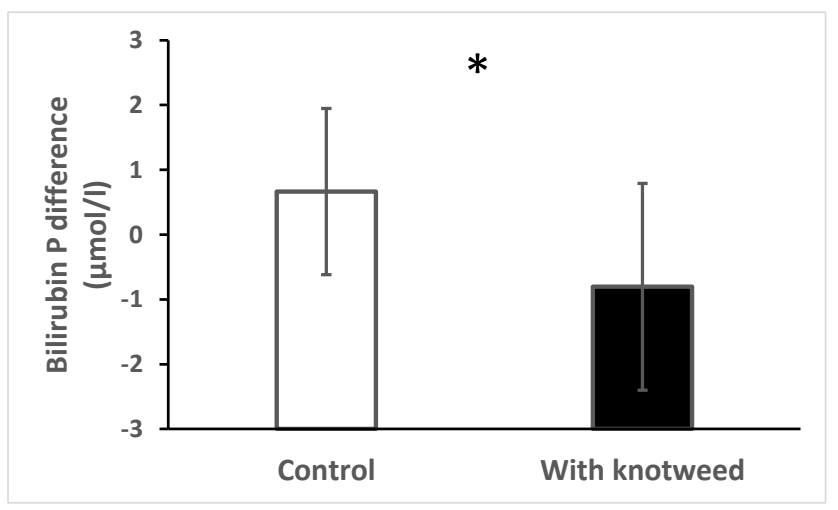

The change of content of leucocytes in the blood of red deer fed on the feeding mixture without the knotweed addition compared to the red deer fed on the mixture with the knotweed addition is also statistically significant (see Fig. 13). Due to the overall reduction in leucocytes, the lower manifestation of pathogenic organisms and positive influence of knotweed may be assumed. It was not possible to compare the results with other authors.

Fig. 13: The change of leucocytes content during experiment in red deer fed on the feeding mixture with the knotweed addition and without the knotweed addition. Mean \pm S.D. Asterisk indicates difference between treatments significant at $P=0.05$.

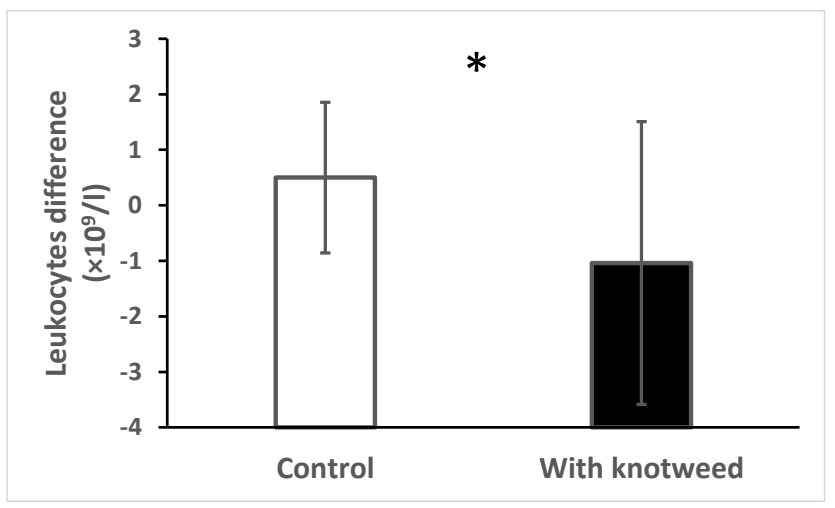

The change of neutrophils value is lower in red deer fed on the feeding mixture with the knotweed addition compared to the red deer fed on the mixture without the knotweed addition, and the results are statistically significant (see Fig. 14). Due to the overall reduction in neutrophiles, the lower manifestation of pathogenic organisms and positive influence of knotweed may be assumed. Barić Rafaj et al. (2011) state the average values to be $58.2 \pm$ 
$10.17 \%$ for fawns and $26.6 \pm 8.17 \%$ for adult individuals. The average values from these authors found for fawns and for adults fall within the range found by us in both groups of adult individuals. The values observed in individuals fed on the mixture with the knotweed addition correspond to the average value for adult individuals stated in the work of Baric Rafaj et al. (2011).

Fig. 14: The change of neutrophils value during experiment in red deer fed on the feeding mixture with the knotweed addition and without the knotweed addition. Mean \pm S.D. Asterisk indicates difference between treatments significant at $P=0.05$.

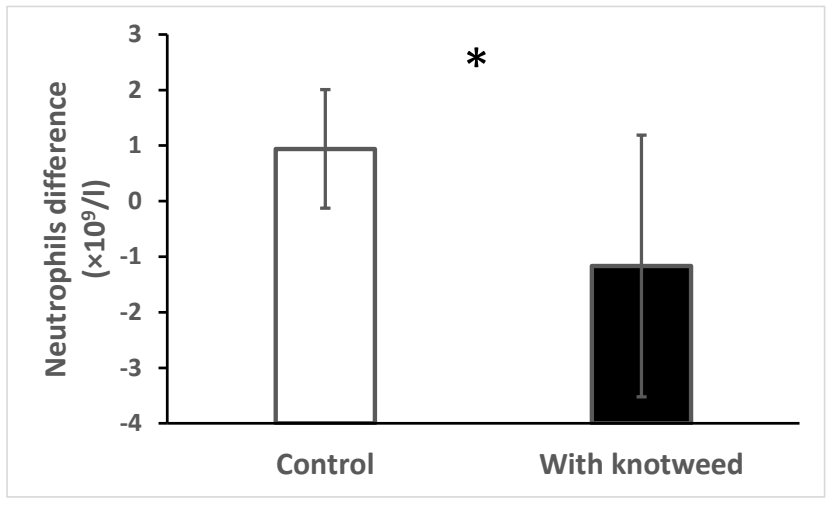

The eosinophile values are higher in red deer fed on the mixture with the knotweed addition compared to red deer fed on the mixture without the knotweed addition, and the results are statistically significant (see Fig. 15). The range of values is lower than the average value stated in the work of Barić Rafaj et al. (2011) $(0.80 \pm 1.03 \%$ for adult individuals and $5.47 \pm 4.67 \%$ for fawns) in both groups. The cause of the lower values found by us, i.e. the reduction of the value of eosinophilic granulocytes (so-called eosinopenia) below the lower limit of the reference range, may be stress during sampling. Our observed values would probably be within the physiological range without the negative influence on the organism.

Fig. 15: Eosinophile values in red deer fed on the feeding mixture with the knotweed addition and without the knotweed addition after experiment in the year 2020. Mean \pm S.D. Asterisk indicates difference between treatments significant at $P=0.05$.

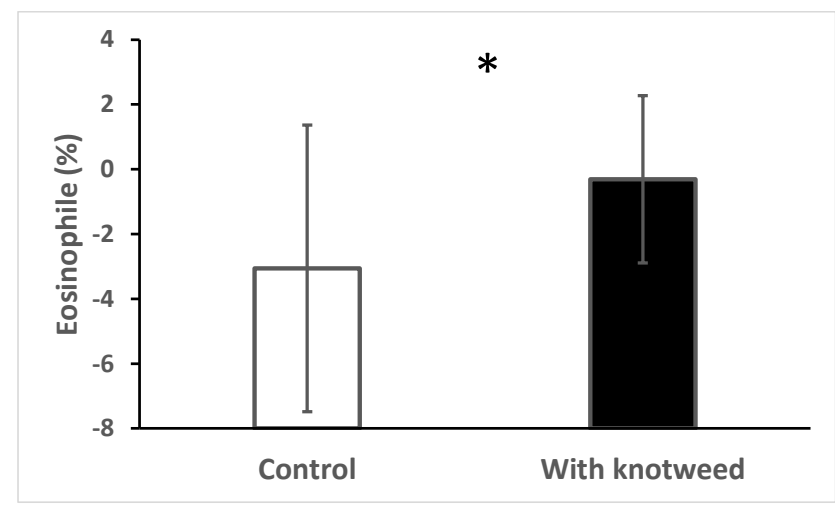


The change of value of basophiles is higher in red deer fed on the feeding mixture with the knotweed addition compared to red deer fed on the mixture without the knotweed addition, and the results are statistically significant (see Fig. 16). The range of values for both tested groups is slightly higher than the average value stated by Barić Rafaj et al. (2011) $-0.40 \pm$ $0.84 \%$ for adult individuals and $1.41 \pm 2.05 \%$ for fawns - while their results are closest to the group fed without the knotweed addition. Our observed values would probably be within the physiological range without the negative influence on the organism.

Fig. 16: The change of value of basophiles during experiment in red deer fed on the feeding mixture with the knotweed addition and without the knotweed addition. Mean \pm S.D. Asterisk indicates difference between treatments significant at $\mathbf{P}=0.05$.

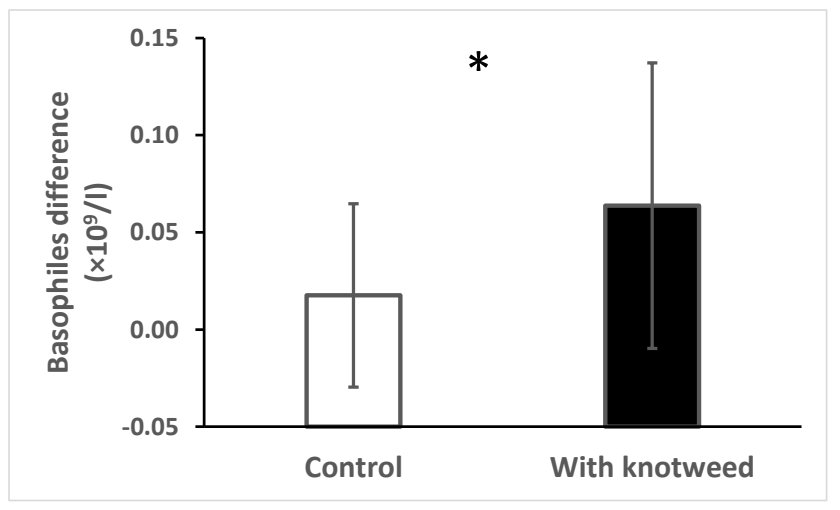

The lymphocyte value is higher in red deer fed on the feeding mixture with the knotweed addition compared to red deer fed on the mixture without the knotweed addition, and the results are statistically significant (see Fig. 17). It cannot be assumed that the feeding mixture with or without knotweed has any influence on these values, and the value is within the physiological range in the vast majority of individuals. In most cases, the values observed by us are rather closer to the average value found within the work of Barić Rafaj et al. (2011) for fawns $(58.2 \pm 10.17 \%)$ than the value of $26.6 \pm 8.17 \%$ for adult individuals.

Fig. 17: The lymphocyte value in red deer fed on the feeding mixture with the knotweed addition and without the knotweed addition after experiment in the year 2020. Mean \pm S.D. Asterisk indicates difference between treatments significant at $P=0.05$.

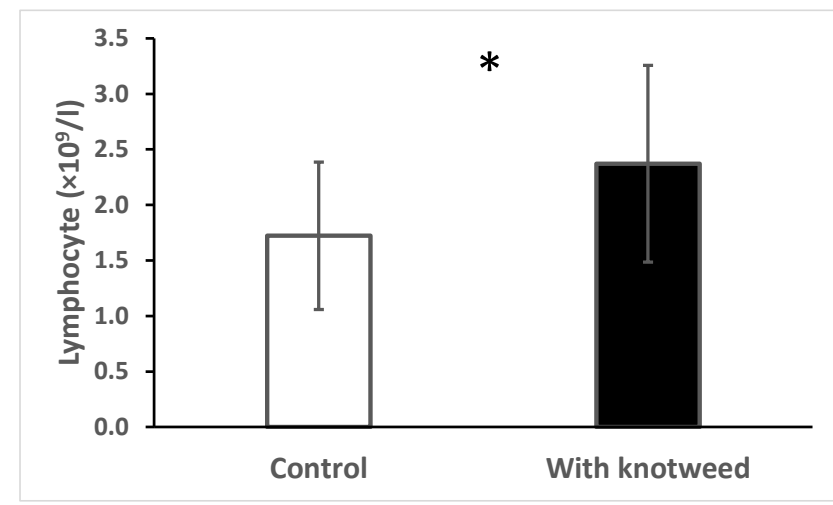


Maděra et al. (2021) point out a different response of pig males and females on knotweed diet. In our study, we did not take into account gender differences, which should be the subject of further research.

\section{CONCLUSION}

Significant differences between the group of roe deer fed on the feeding mixture with the knotweed addition and the group fed on the mixture without the knotweed addition were found in the content of urea, bilirubin $\mathrm{T}$ and lymphocytes. For red deer, the significant differences were found in urea content, creatinine, total protein, globulins, A/G ratio, triglycerides, cholesterol, bilirubin T, leucocytes, neutrophils, eosinophils, basophils and lymphocytes. The results show that enriching feed mixtures with knotweed creates a positive influence on the microbiome in the digestive system and leads to a better utilisation of nutrients in both red and roe deer. It is also possible to assume a lower manifestation of pathogenic organisms. For these reasons, feeding mixtures with the knotweed addition are especially usable on farms and in hobby and professional breeding. It is also possible to use them for feeding deer in open hunting grounds. In conclusion, it can be stated that observed results in individuals fed on the mixture with the knotweed addition seem to be original, and it was not possible to compare them with other authors. What more, production of feeding mixture with the knotweed addition could stimulate the utilisation of knotweed from the open landscape as a potential source of biomass and thus it can help to eradicate the knotweed at least partially from the landscape.

\section{ACKNOWLEDGEMENTS}

This work was supported by the project no. TH02010325 of the Technology Agency of the Czech Republic.

\section{CONFLICTS OF INTEREST}

The authors declare no conflict of interest.

\section{REFERENCES}

Adrian, M., Jeandet, P., Veneau, J., Weston, L.A., Bessis, R., (1997). Biological activity of resveratrol, a stilbenic compound from grapevines, against Botrytis cinerea, the causal agent for gray mold. Journal of Chemical Ecology. 23(7): 1689-1702.

Ahmed, S.T., Hossain, M.E., Kim, G.M., Hwang, J.A., Ji H., Yang, C.J., (2013). Effects of resveratrol and essential oils on growth performance, immunity, digestibility and fecal microbial shedding in challenged piglets. Asian-Australasian Journal of Animal Sciences. 26(5):683-690.

Anantaphruti, M., Terada, M., Ishii, A.I., Kino, H., Sano, M., Kuroyanagi, M., \& S. Fukushima (1982). Chemotherapy of parasitic helminths: 11. In vitro effects of various drugs on the motor activity of adult Schistosoma japonicum. JPN J Parasitol. 31(4): 321-328.

Barić, Rafaj, R., Tončić, J., Vicković, I., Šoštarić, B., (2011). Haematological and biochemical values of farmed red deer (Cervus elaphus). Vet. arhiv. 81, 513-523, 2011.

Bavaresco, L, Pezzutto, S, Ragga, A, Ferrari, F, Trevisan, M., (2001). Effect of nitrogen 
Ernst M., Maděra P., Frantík T., Novák J., Vencl Š.: The Effect of Reynoutria $\times$ bohemica on the Condition of Capreolus capreolus and Cervus elaphus

supply on trans-resveratrol concentration in berries of Vitis vinifera L. cv. Cabernet Sauvignon. Vitis. 40: 229-230.

Bavaresco, L., Vezzulli, S., Battilani, P., Giorni, P., Pietri, A., Bertuzzi, T., (2003). Effect of ochratoxin A-producing Aspergilli on stilbenic phytoalexin synthesis in grapes. Journal of Agricultural and Food Chemistry. 51(21): 6151-6157.

Brasnyo, P., Molnar, G.A., Mohas, M., Marko, L., Laczy, B., Cseh, J., Mikolas, E., Szijarto, I.A., Merei, A., Halmai, R., Meszaros, L.G., Sumegi, B., Wittmann, I., (2011). Resveratrol improves insulin sensitivity, reduces oxidative stress and activates the Aktpathway in type 2 diabetic patients. Br. J. Nutr. 106: 383-389.

Chan, M.M.Y., (2002). Antimicrobial effect of resveratrol on dermatophytes and bacterial pathogens of the skin. Biochem. Pharmacol.. 63: 99-104.

Claude, L., (2017). The impact of invasive knotweed species (Reynoutria spp.) on the environment: review and research perspectives. Biological Invasions, 19 (8): 2319-2337. https://doi.org/10.1007/s10530-017-1444-y.

Cui Q., Fu Q., Zhao Z., Song X., Yu J., Yang Y., Sun K., Bai L., Tian Y., Chen S., (2018). Protective effects and immunomodulation on piglets infected with rotavirus following resveratrol supplementation. PLoS One. 13(2):e0192692.

Dal-Pan, A., Blanc, S., Aujard, F., (2010). Resveratrol suppresses body mass gain in aseasonal non-human primate model of obesity. BMC Physiol. 10: 11.

Docherty, J.J., Fu, M.M., Tsai, M., (2001). Resveratrol selectively inhibits Neisseria gonorrhoeae and Neisseria meningitidis. J. Antimicrob. Chemother. 47: 243-244.

El-Mowafy, A.M., Alkhalaf, M., (2003). Resveratrol activates adenylyl-cyclase in human breast cancer cells: a novel, estrogen receptor-independent cytostatic mechanism. Carcinogenesis. 24: 869-873.

Ferry-Dumazet, H., Garnier, O., Mamani-Matsuda, M., Vercauteren, J., Belloc, F., Billiard, C., Dupouy, M., Thiolat, D., Kolb, J.P., Marit, G., Reiffers, J., Mossalayi, M.D., (2002). Resveratrol inhibits the growth and induces the apoptosis of both normal and leukemic hematopoietic cells. Carcinogenesis. 23: 1327-1333.

Filip, V., Plockova, M., Smidrkal, J., Spickova, Z., Melzoch, K., Schmidt, S., (2003). Resveratrol and its antioxidant and antimicrobial effectiveness. Food Chemistry. 83(4): 585-593.

Fu, Z.Y., Han, J.X., Huang, H.Y., (2007). Effects of emodin on gene expression profile in small cell lung cancer NCI-H446 cells. Chinese Medical Journal. 120(19): 1710-1715.

Handler, N., (2011). Equithrive-pioneering resveratrol therapy. In: Sport Horse. Retrieved September 20, 2013, from http://www.sporthorsez.com.

Holešovská Z., Volný T., Kotrbáček V., Doubek J., (2009). Influence of ethanol solution of resveratrol on leukocyte count and phagocytic activity in piglets. Bulletin of the Veterinary Institute in Pulawy. 53:449-453.

Jacob C., Kirsch G., Slusarenko A., Winyard P.G., Burkholz T., (2014). Recent Advances in Redox Active Plant and Microbial Products: From Basic Chemistry to Widespread Applications in Medicine and Agriculture. Springer. NJ, USA.

Jeong, E.T., Jin, M.H., Kim, M.S., Chang, Y.H., Park, S.G., (2010). Inhibition of melanogenesis by piceid isolated from Polygonum cuspidatum. Arch. Pharm. Res. 33: 13311338 . 
Jung, H.J., Hwang, I.A., Sung, W.S., Kang, H., Kang, B.S., Seu, Y.B., Lee, D.G., (2005). Fungicidal effect of resveratrol on human infectious fungi. Archives of Pharmacal Research. 28(5): 557-560.

Kerem, Z., Bilkis, I., Flaishman, M.A., Sivan, U., (2006). Antioxidant activity and inhibition of alpha-glucosidase by trans-resveratrol, piceid, and a novel trans-stilbene from the roots of Israeli Rumex bucephalophorus L. Journal of Agricultural and Food Chemistry. 54(4): 1243-1247.

Kohnen S., Franck T., Van Antwerpen P., Boudjeltia K.Z., Mouithys-Mickalad A., Deby C., Moguilevsky N., Deby-Dupont G., Lamy M., Serteyn D., (2007). Resveratrol inhibits the activity of equine neutrophil myeloperoxidase by a direct interaction with the enzyme. Journal of Agricultural and Food Chemistry. 55:8080-8087.

Küker, S., Huber, N., Evans, A., Kjellander, P., Bergvall, U.A., Jones, K.L., Arnemo, J.M., (2015). Hematology, serum chemistry, and serum protein electrophoresis ranges for free-ranging roe deer (Capreolus capreolus) in Sweden. J Wildl Dis. 2015 Jan; 51(1):269-73. doi: 10.7589/2014-02-025. PMID: 25375949.

Lawless, P., (2010). Two New Research Projects Study on Resveratrol's Effect on EMS. Retrieved September 30, 2013, from Lexington, Kentucky: Biological Prospects/Equithrive; 2010.

Lu, Y.Y., Zhang, J.L., Qian, J.M., (2008). The effect of emodin on VEGF receptors in human colon cancer cells. Cancer Biotherapy and Radiopharmaceuticals. 23(2): 222-228.

Luque, G.M., Bellard, C., Bertelsmeier, C., Bonnaud, E., Genovesi, P., Simberloff, D., Courchamp, F., (2014). The 100th of the world's worst invasive alien species. Biol. Invasions, 16, 981-985. https://doi.org/10.1007/s10530-013-0561-5.

Maděra, P., Kovářová, M., Frantík, T., Filipčík, R., Novák, J., Vencl, Š., Maděrová, L., Rozkot, M., Kuchařová, S., Václavková, E., Truněčková, J., Volková, J., Nývltová, Z., Bartoš, M., (2021). Effect of Knotweed in Diet on Physiological Changes in Pig. Agriculture, 11, 169. https://doi.org/10.3390/agriculture11020169.

Mandák, B., Pyšek, P., Bímová, K., (2004). History of the invasion and distribution of Reynoutria taxa in the Czech Republic: a hybrid spreading faster than its parents. Preslia, 76 (1): 15-64.

Marco, I, Lavín, S., (1999). Effect of the method of capture on the haematology and blood chemistry of red deer (Cervus elaphus). Res Vet Sci. 1999 Apr; 66(2):81-4. doi: 10.1053/rvsc.1998.0248. PMID: 10208884.

Muto, A., Hori, M., Sasaki, Y., Saitoh, A., Yasuda, I., Maekawa, T., Uchida, T., Asakura, K., Nakazato, T., Kaneda, T., Kizaki, M., Ikeda, Y., Yoshida, T., (2007). Emodin has a cytotoxic activity against human multiple myeloma as a Janus-activated kinase 2 inhibitor. Mol. Cancer Ther. 6(3): 987-94.

Pecere, T., Gazzola, M.V., Mucignat, C., Parolin, C., Dalla, Vecchia F., Cavaggioni, A., Basso, G., Diaspro, A., Salvato, B., Carli, M., Palu, G., (2000). Aloe-emodin is a new type of anticancer agent with selective activity against neuroectodermal tumors. Cancer Research. 60(11): 2800-2804.

Pezzuto, J.M., (2008). Resveratrol as an inhibitor of carcinogenesis. Pharm. Biol. 46: 443573.

Roman, V., Billard, C., Kern, C., Ferry-Dumazet, H., Izard, J.C., Mohammad, R., Mossalayi, D.M., Kolb, J.P., (2002). Analysis of resveratrol-induced apoptosis in human B-cell chronic leukaemia. British Journal of Haematology. 117: 842-851. 
Ernst M., Maděra P., Frantík T., Novák J., Vencl Š.: The Effect of Reynoutria $\times$ bohemica on the Condition of Capreolus capreolus and Cervus elaphus

Rowen, R., (2013). Resveratrol.Advanced Bionutritionals, Norcross Georgia. United States; Retrieved September 15, 2014, from http://www.advancedbionutritional.com/.

Scherer, P., Pokorádi, J., Ernst, M., (2019). Food supply and nutrition of roe and red deer. Myslivost. 12/2019, vol. 67: 16-21. ISSN 0323-214X.

Schulze, K., Schreiber, L., Szankowski, I., (2005). Inhibiting effects of resveratrol and its glucoside piceid against Venturia inaequalis, the causal agent of apple scab. J.Agr. Food Chem. 53: 356-362.

Shaw R., Bryner S., Tanner, R., (2009). The life history and host range of the Japanese knotweed psyllid, Aphalara itadori Shinji: Potentially the first classical biological weed control agent for the European Union. Biological Control, 49 (2): 105-113. https://doi.org/10.1016/j.biocontrol.2009.01.016.

Ulrich, S., Wolter, F., Stein, J.M., (2005). Molecular mechanisms of the chemopreventive effects of resveratrol and its analogs in carcinogenesis. Molecular Nutrition \& Food Research. 49: 452-461.

Wolter, F., Ulrich, S., Stein, J., (2004). Molecular mechanisms of the chemopreventive effects of resveratrol and its analogs in colorectal cancer: Key role of polyamines? Journal of Nutrition. 134: 3219-3222.

Zambito, J.L., (2011). Effects of resveratrol supplementation on glycemic response and oxidant status in moderately exercised mature quarter horse geldings [master's thesis]. Morgantown: West Virginia Univ.; 2011. Retrieved September 8, 2014, from http://www.proquest.com.

Žele, D., Venguš, G., (2012). Biochemical indicators in serum of free-ranging roe deer (Capreolus capreolus) in Slovenia. ACTA VET. BRNO 2012, 81: 377-381; doi:10.2754/avb201281040377. 